ANALIZA PROCESÓW TRANSPORTU WEWNĘTRZNEGO

I MAGAZYNOWANIA W ASPEKCIE BEZPIECZEŃSTWA W WYBRANYM

PRZEDSIECBIORSTWIE PRODUKCYJNYM

\title{
ANALISIS OF INTERNAL STORAGE AND TRANSPORT PROCESSES IN A SELECTED PRODUCTION COMPANY IN THE CONTEXT OF OCCUPATIONAL HEALTH AND SAFETY
}

\author{
Tomasz EWERTOWSKI \\ tomasz.ewertowski@put.poznan.pl, \\ Dominika BLASZAK \\ dominika.blaszak@student.put.poznan.pl \\ Politechnika Poznańska \\ Wydział Inżynierii Zarządzania \\ Katedra Ergonomii i Inżynierii Jakości
}

\begin{abstract}
Streszczenie: Celem niniejszego artykułu jest zidentyfikowanie kluczowych zagrożeń bezpieczeństwa, które maja wplyw na procesy transportu wewnętrznego i magazynowania w badanym przedsiębiorstwie oraz przedstawienie możliwych rozwiązań $w$ celu ich usprawnienia. Umożliwi to również poszerzenie $i$ ugruntowanie wiedzy z badanego zakresu, na co składa się zaprezentowanie procesów magazynowania i transportu wewnętrznego oraz ich związu $z$ bezpieczeństwem $w$ danym przedsiębiorstwie produkcyjnym, a w szczególności analizy wypadków oraz zdarzeń potencjalnie wypadkowych związanych z tymi procesami. Na potrzeby niniejszego opracowania dokonano badania metoda sondażu diagnostycznego z zastosowaniem techniki ankiety. Wykonano je na wszystkich pracownikach zatrudnionych w zakładzie, którzy maja do czynienia z transportem wewnętrznym oraz magazynowaniem. Przedstawione $w$ pracy zagadnienia, rozważania $i$ wnioski powstały na podstawie studiów literatury przedmiotu oraz wyników badań.

Abstract: The aim of this work and research carried out in it, is to identify crucial hazards associated with processes of internal storage and transport in a selected production company and to find appropriate remedial actions to reduce these hazard risks. Moreover the aim is to broaden and consolidate the knowledge of the studied range, which consists of presenting the processes of internal storage and transport and their relationship with safety in a production company, in particular the analysis of accidents and incidents related to these processes. For the purpose of this study, a diagnostic survey was conducted using a survey technique. They were completed by all employees who deal with internal transport and storage. The issues, considerations and conclusions presented in the work were based on literature studies and research results.
\end{abstract}

Słowa kluczowe: Logistyka, magazynowanie, transport wewnętrzny, bezpieczeństwo i higiena pracy, wypadki Key words: Logistic, internal transport, internal storage, occupational health and safety, accidents 


\section{WSTĘP}

W niniejszym artykule został poruszony problem dotyczący szeroko rozumianych procesów magazynowania i transportu wewnętrznego występujących w przedsiębiorstwie produkcyjnym oraz ich związku z bezpieczeństwem i higieną pracy.

Przedsiębiorstwo, które zostało poddane badaniu zalicza się do małych i obecnie zatrudnia ok. 40 pracowników, z czego 70\% osób to pracownicy produkcji. Firma zlokalizowana jest w województwie wielkopolskim. Oferta firmy obejmuje produkcję naziemnych urządzeń magazynujących i dozujących oraz profesjonalną obsługę gwarancyjną i serwisową produkowanych urządzeń.

Logistyką można nazwać zarządzanie działaniami przemieszczania oraz składowania, których zadaniem jest ułatwianie przepływu produktów z miejsc pochodzenia do ostatecznego odbiorcy, czyli klienta. W logistyce magazynowanie oraz transport wewnątrzzakładowy stanowią jedne z podstawowych obszarów działalności, a co ważniejsze są ze sobą ściśle związane i od siebie zależne. W celu ich sprawnego funkcjonowania niezbędni są ludzie, którzy posiadają odpowiednie kwalifikacje i doświadczenie, właściwa organizacja pracy, sprawny i bezpieczny sprzęt oraz przyjazne środowisko, zarówno technologiczne jak i naturalne.

Szeroko rozumiane bezpieczeństwo to teoria i praktyka zapewnienia (przetrwania) danego podmiotu w niepewnym środowisku, przy zachowaniu przezeń swobody realizacji własnych interesów. Obecnie bezpieczeństwo można zdefiniować jako pożądany stan, osiągany poprzez indywidualne i grupowe, systematyczne identyfikowanie zagrożeń, szacowanie i redukcję ryzyka do najniższego akceptowalnego poziomu, celem ochrony zdrowia i życia pracowników związanych z funkcjonowaniem operacyjnym. Mając na względzie powyższą interpretację terminu "bezpieczeństwo", można powiedzieć, iż polityka bezpieczeństwa przedsiębiorstwa produkcyjnego powinna skupiać się na działaniach, które pozwolą na ochronę pracowników jak i samej organizacji, w tym procesów jakie w niej zachodzą. Wszelkim procesom logistycznym nieoderwalnie towarzyszą aspekty BHP. Procedury oraz zasady BHP różnią się od siebie w zależności od procesu, co wynika z faktu, iż zagrożenia występujące $\mathrm{w}$ procesie transportu wewnętrznego różnią się od tych, które możemy wyróżnić $\mathrm{w}$ procesie magazynowania.

Celem niniejszego badania jest zidentyfikowanie kluczowych zagrożeń bezpieczeństwa, które mają wpływ na procesy transportu wewnętrznego i magazynowania w wybrany przedsiębiorstwie produkcyjnym oraz przedstawienie możliwych rozwiązań w celu ich usprawnienia. Ocena jakości analizowanych procesów i ich bezpieczeństwa 
umożliwia identyfikację i odkrycie obszarów, które wymagają poprawy lub wzmocnienia. Usprawnienie ich może skutkować wzrostem bezpieczeństwa badanych procesów. W badaniu skupiono się w głównej mierze na szeroko rozumianym czynniku ludzkim, ponieważ jest on czynnikiem sprawczym największej statystycznie liczby wypadków i zdarzeń potencjalnie wypadkowych. W związku z potrzebą utrzymania pożądanego i akceptowalnego stanu bezpieczeństwa wybranych procesów logistycznych, które zachodzą w badanym przedsiębiorstwie podjęto szereg działań, w tym: przeprowadzono badania ankietowe wśród pracowników produkcyjnych, przeanalizowano wypadki oraz zdarzenia potencjalnie wypadkowe, które miały związek z procesem transportu wewnętrznego oraz procesem magazynowania, a następnie przeanalizowano otrzymane wyniki. $\mathrm{Na}$ ich podstawie przedstawiono i wdrożono rozwiązania, mające na celu usprawnienie procesów transportu wewnętrznego i magazynowania poprzez zwiększenie bezpieczeństwa, co ma bezpośrednie przełożenie na poprawę funkcjonowania przedsiębiorstwa. W badaniu wykorzystano takie metody badawcze jak: analiza i synteza, dedukcja, wywiad, badania ankietowe, wnioskowanie i analiza porównawcza, a także narzędzia badawcze jak: arkusz badania ankietowego oraz programy komputerowe MS Word i MS Excel.

\section{CHARAKTERYSTYKA PROCESÓW MAGAZYNOWANIA I TRANSPORTU WEWNETRZNEGO W PRZEDSIĘBIORSTWIE}

$\mathrm{Na}$ proces magazynowania składa się zespół działań operacyjnych, które związane są z przyjmowaniem, składowaniem, kompletacją i wydawaniem dóbr materialnych w odpowiednio dostosowanych do tego miejscach, a równocześnie spełniają sprecyzowane warunki technologiczne i organizacyjne. Gospodarka magazynowa jest jednym z najważniejszych elementów w sferze logistyki. Umiejętność poprawnej organizacji procesów magazynowania powoduje szybki przepływ materiałów od dostawców poprzez system produkcyjny, aż do potencjalnego klienta. Odpowiednie przygotowanie magazynu i poprawne opracowanie systemu logistycznego powodują, iż cały przepływ materiałów $\mathrm{w}$ procesie logistycznym przebiega efektywnie i poprawnie.

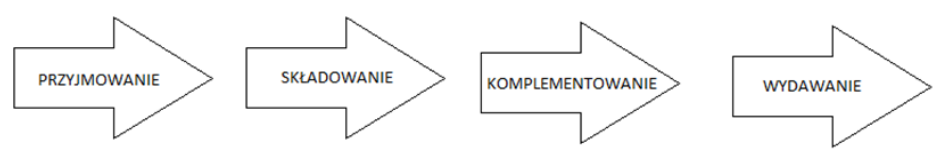

Rys. 1. Fazy procesu magazynowania

Źródło: Opracowanie własne na podstawie Dudziński i Kizyn, 2000, s. 17. 
Procesy transportu wewnętrznego odbywają się na terenie przedsiębiorstwa produkcyjnego i obejmują następujące operacje: przyjęcie półproduktów i innych ładunków, transport produkcyjny, wysłanie ładunku wyrobów gotowych do ostatecznego odbiorcy. Głównymi czynnikami mającymi wpływ na transport wewnątrzzakładowy są między innymi natężenie strumienia wyrobów, ich masa i objętość, rodzaje procesów technologicznych oraz rodzaj produkcji.

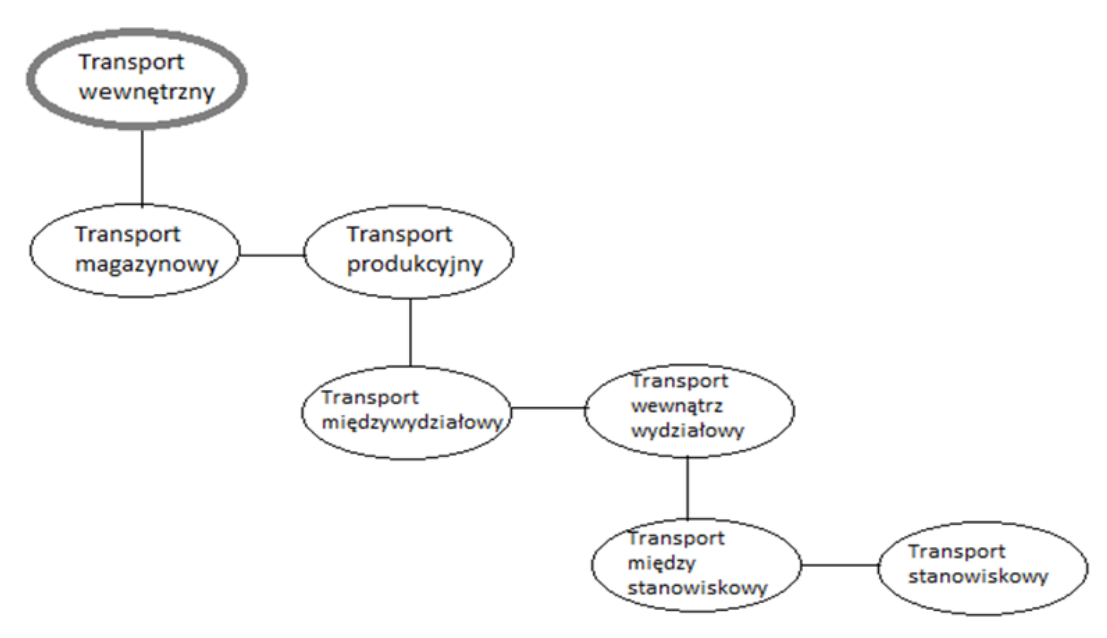

Rys. 2. Klasyfikacja transportu wewnętrznego

Źródło: Grzybowska K., 2010, s. 236.

Zapewnienie bezpiecznego transportu wewnętrznego wymaga odpowiednich i dostosowanych do tego urządzeń i pojazdów, które powinny być dostępne do użytku osób uprawnionych. W celu zapewnienia przemieszczania ładunków zgodnie z bezpiecznymi zasadami przy jak najniższych kosztach należy zastosować odpowiednie środki transportu, przejścia i trasy komunikacyjne. W transporcie bliskim używane są urządzenia transportowe, takie jak: wózki jezdniowe, suwnice, podnośniki czy przenośniki. Każde $\mathrm{z}$ tych urządzeń na swój indywidualny sposób może powodować wypadki, czyli inaczej mówiąc może być źródłem zagrożenia. Odpowiedni dobór oraz użytkowanie tych urządzeń stanowi podstawowy element zapewniający bezpieczeństwo pracowników i całego zakładu.

Hala magazynowo-produkcyjna badanego przedsiębiorstwa mieści się w niewielkim parku przemysłowym i zajmuje około $900 \mathrm{~m}^{2}$ powierzchni. Połączona jest z pomieszczeniem biurowym o znacznie mniejszej powierzchni tj. około $150 \mathrm{~m}^{2}$. Hala podzielona jest na dwa obszary, to znaczy na obszar magazynowania, który zajmuje około $25 \%$ powierzchni oraz obszar produkcji. Wewnątrz hali magazynowane są wszelkie półprodukty służące do produkcji zbiorników oraz inne części serwisowe. Większe gabarytowo części, składowane są na regale paletowym rzędowym. Na terenie produkcyjnym hali magazynowane są zbiorniki, które są w trakcie produkcji lub gotowe, czekające na wydanie na zewnątrz. Ze względu na 
duże rozmiary produkowanych wyrobów, po zakończeniu produkcji zbiorniki muszą jak najszybciej opuścić halę, aby zapewnić miejsce kolejnym produkcjom i by utrzymana była jej ciągłość.

Do kluczowych stanowisk w badanym przedsiębiorstwie związanych $\mathrm{z}$ procesami magazynowania i transportu wewnętrznego należy zaliczyć: główny magazynier, specjalista ds. zaopatrzenia, magazynier/operator wózka widłowego, kierownik produkcji, specjalista ds. transportu oraz operator wózka widłowego/pracownik produkcji.

\section{IDENTYFIKACJA ZAGROŻEŃ BEZPIECZEŃSTWA BADANYCH PROCESÓW}

W badanym przedsiębiorstwie wykorzystano takie metody badawcze jak badania ankietowe wśród pracowników produkcyjnych oraz analiza wypadków oraz zdarzeń potencjalnie, które miały związek z procesem transportu wewnętrznego oraz procesem magazynowania.

\subsection{Badanie ankietowe}

Część badawcza niniejszej pracy opiera się o zastosowanie metody sondażu diagnostycznego, z użyciem techniki ankiety. W tym celu został zbudowany w odpowiedni sposób zestaw prostych pytań zamkniętych, które umieszczono w kwestionariuszu ankietowym, o trzech możliwościach odpowiedzi. Kwestionariusz użyty w badaniach został zbudowany tak, aby spełniał najważniejsze postulaty dotyczące budowy kwestionariusza ankietowego, m. in.:

- pytania sformułowane są tak, aby w sposób właściwy nawiązywały do stopnia poinformowania badanego i z tego powodu nie wywoływało zażenowania,

- kwestionariusz składa się w języku zrozumiałym dla badanych,

- temat jest rozwijany w kolejnych pytaniach w taki sposób, aby odpowiadał kryteriom logiki,

- unikano długich i skomplikowanych zdań oraz wieloznaczności,

- pytania nie sugerują żadnej odpowiedzi jako najwłaściwszej, innymi słowy unikano tendencyjności,

- jedno pytanie odnosi się do jednego zagadnienia (Wójcik, 2012, s. 96-97).

Grupę badawczą stanowili wszyscy pracownicy badanego przedsiębiorstwa związani z badanymi procesami. Zostali oni wcześniej poinformowani o konieczności przeprowadzania ankiet, podkreślając, iż wszystkie wypowiedzi są anonimowe oraz mają służyć celom badawczym. Celem badań było poznanie opinii respondentów na temat bezpieczeństwa procesów magazynowania i transportu wewnętrznego $\mathrm{w}$ badanym przedsiębiorstwie, co 
umożliwi poprawę bezpieczeństwa tych procesów i jednocześnie podwyższy poziom bezpieczeństwa samych respondentów.

\subsubsection{Charakterystyka metodyki działań badawczych}

W celu rzetelnego przeprowadzenia badań w zakresie bezpieczeństwa procesów magazynowania i transportu wewnętrznego jako narzędzie badawcze został zastosowany kwestionariusz, który został skonstruowany na potrzeby niniejszej pracy.

Kwestionariusz ankiety opracowany został po wcześniejszej analizie istniejących kwestionariuszy z tej tematyki, jednak pytania skonstruowane zostały w taki sposób, aby były one zrozumiałe dla wszystkich pracowników. Odpowiedzi ograniczają się do trzech możliwości, aby wyniki były konkretne oraz by mieć świadomość, które konkretnie obszary należałoby przeanalizować i poprawić. Kwestionariusz obejmuje swoim zakresem cztery następujące części:

- dane socjodemograficzne,

- stosunek pracowników do bezpieczeństwa,

- wiedza na temat procesów magazynowania oraz transportu wewnętrznego i ich bezpieczeństwa,

- opinia na temat pracy.

Każda z grup tematycznych składa się z od czterech do dwunastu pytań szczegółowych.

\subsubsection{Analiza wyników badań}

W badanym przedsiębiorstwie wśród pracowników zostało rozdanych 30 ankiet, z czego zwrotnie uzyskanych zostało 28. Stanowi to bardzo dobry wynik, ponieważ jest to 93\% pracowników przedsiębiorstwa związanych z badanymi procesami. Kwestionariusz ten składał się z 40 pytań tematycznych, na które ankietowani udzielili odpowiedzi wybierając jedną z trzech dostępnych propozycji. Ze względu na niewielką liczbę egzemplarzy, do obliczania wyników zastosowano metodę zarówno ręczną jak i komputerową. Pierwsza metoda polega na ręcznym segregowaniu kwestionariuszy w grupy jednorodne pod względem sposobu odpowiedzi udzielonych na poszczególne pytania, a następnie na ustaleniu liczb dotyczących poszczególnych typów odpowiedzi. Metoda komputerowa polega na wprowadzeniu odpowiedzi do programu Excel i dokonaniu potrzebnych obliczeń. Poniżej przedstawiono poszczególne wyniki i zależności z danych uzyskanych drogą ankiety.

Pierwszym pytaniem z pytań socjodemograficznych było pytanie o płeć i tak 29\% respondentów to kobiety, a pozostałe $71 \%$ to mężczyźni. Poniżej przedstawiono rozkład wieku badanych (Rysunek 3.). 


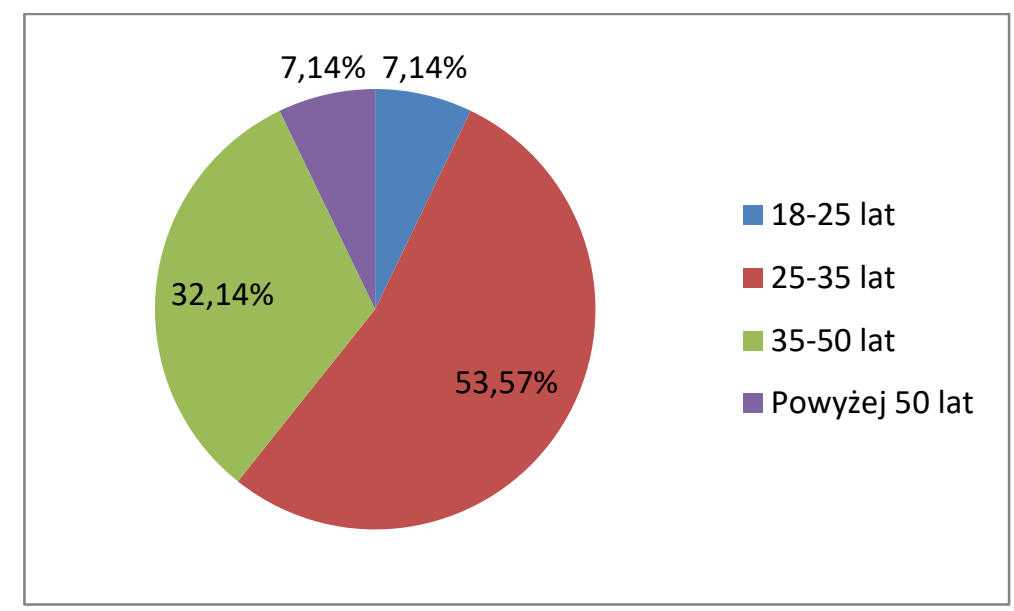

Rys. 3. Procentowy rozkład wieku pracowników

Źródło: opracowanie własne na podstawie przeprowadzonej ankiety.

Przedsiębiorstwo produkcyjne ceni sobie młodych pracowników, dając im szansę na rozwój. $\mathrm{Z}$ tego względu ponad połowa pracowników stanowi grupę wiekową 25-35 lat. Ze względu na to, iż praca na produkcji jest pracą wysiłkową grupa wiekowa powyżej 50 lat stanowi w zakładzie jedynie około $7 \%$.

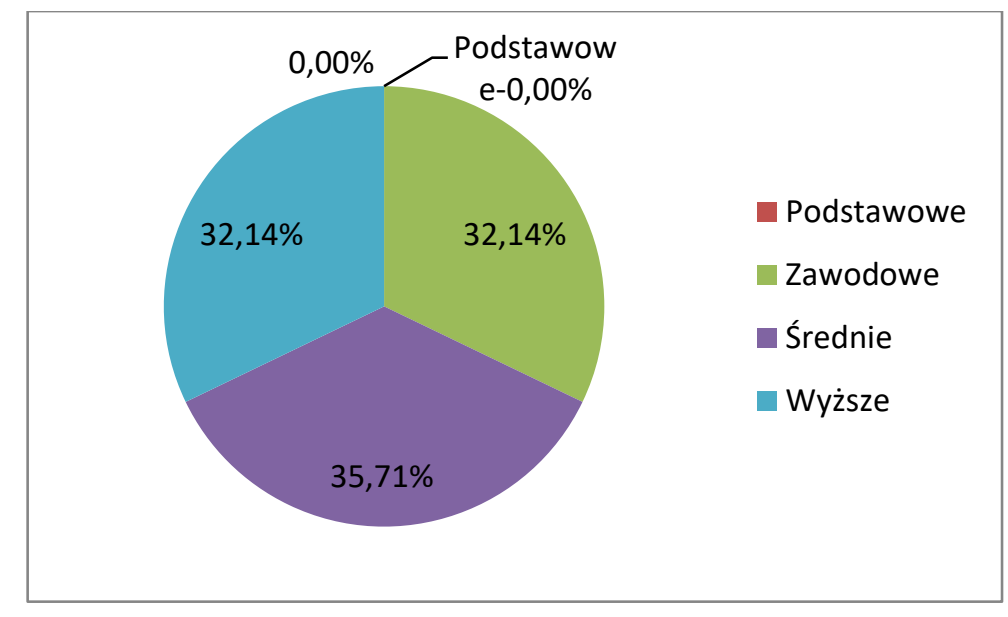

Rys. 4. Procentowy rozkład poziomu wykształcenia pracowników

Źródło: opracowanie własne na podstawie przeprowadzonej ankiety.

Jak wynika z Rys. 4, żaden z respondentów nie posiada wykształcenia podstawowego, a rozkład wykształcenia zawodowego, średniego i wyższego jest na podobnym poziomie. Zgodnie z wcześniejszymi informacjami większość badanych pracowników stanowi grupe pracowników fizycznych co prezentuje Rys. 5. Prawie 11\% respondentów zaznaczyło odpowiedź "inne" co oznacza stanowiska pracy, które obejmują pracę biurową i fizyczną. Należą do nich między innymi kierownik produkcji, pracownik działu technicznego oraz główny magazynier. Ze względu na specyfikację pracy dzielą czas na pracę przy maszynach oraz pracę przy komputerach. Kolejny Rys. 6. prezentuje odpowiedź na pytanie "Czy kiedykolwiek uległeś wypadkowi przy pracy?". 


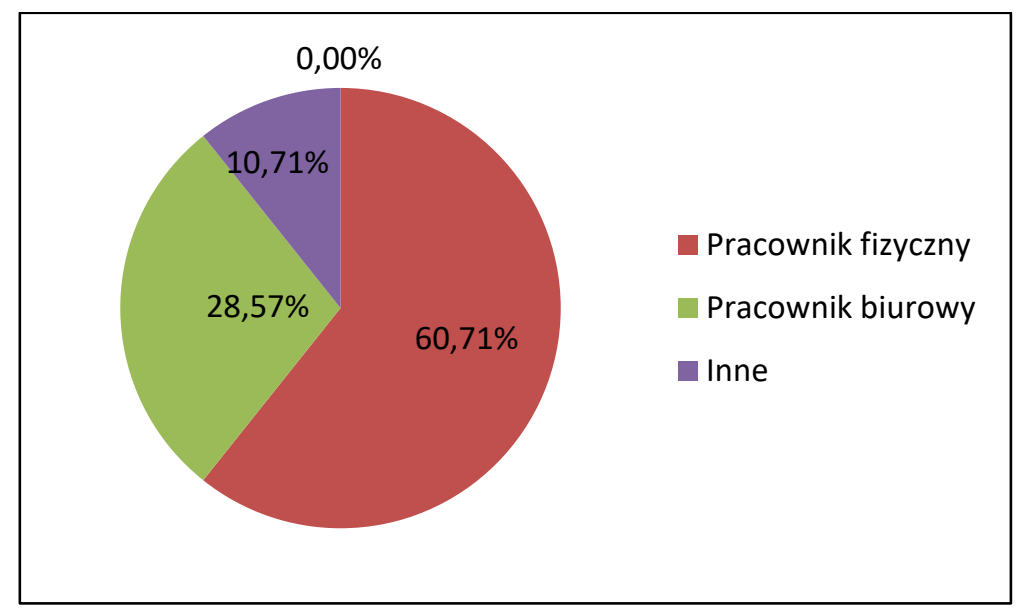

Rys. 5. Procentowy rozkład stanowisk wśród pracowników

Źródło: opracowanie własne na podstawie przeprowadzonej ankiety

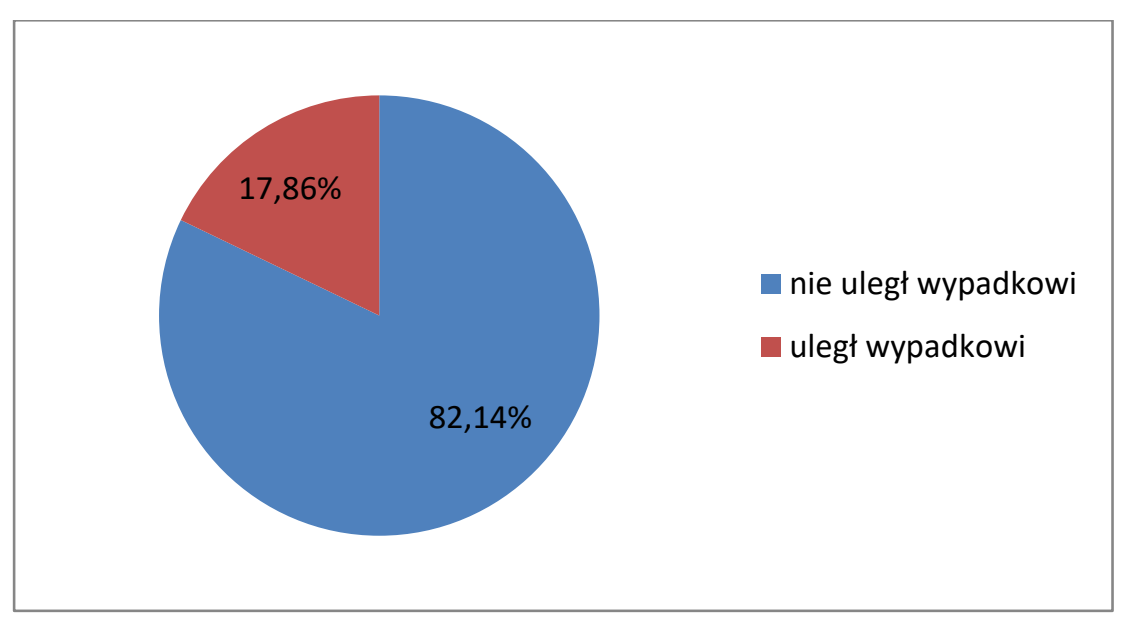

Rys. 6. Procentowy udział pracowników, którzy kiedykolwiek ulegli wypadkowi przy pracy Źródło: opracowanie własne na podstawie przeprowadzonej ankiety.

Przeważająca część pracowników nigdy nie uległa wypadkowi przy pracy, co świadczy o ich wysokim poziomie znajomości przepisów i zasad bezpieczeństwa oraz o bezpiecznym środowisku pracy, w którym przebywają. Wciąż prawie $18 \%$ badanych doznało urazu związanego z miejscem pracy. Jest to powód, dla którego należy zwiększać świadomość istoty BHP między pracownikami. Przedostatnim pytaniem z pierwszej grupy było pytanie dotyczące udziału badanych pracowników sytuacji potencjalnie wypadkowej. Rys. 7 przedstawia zależność udziału respondentów w sytuacji, która prawie zakończyła się wypadkiem. Wyniki znacznie różnią się od wyników z Rys. 6. 


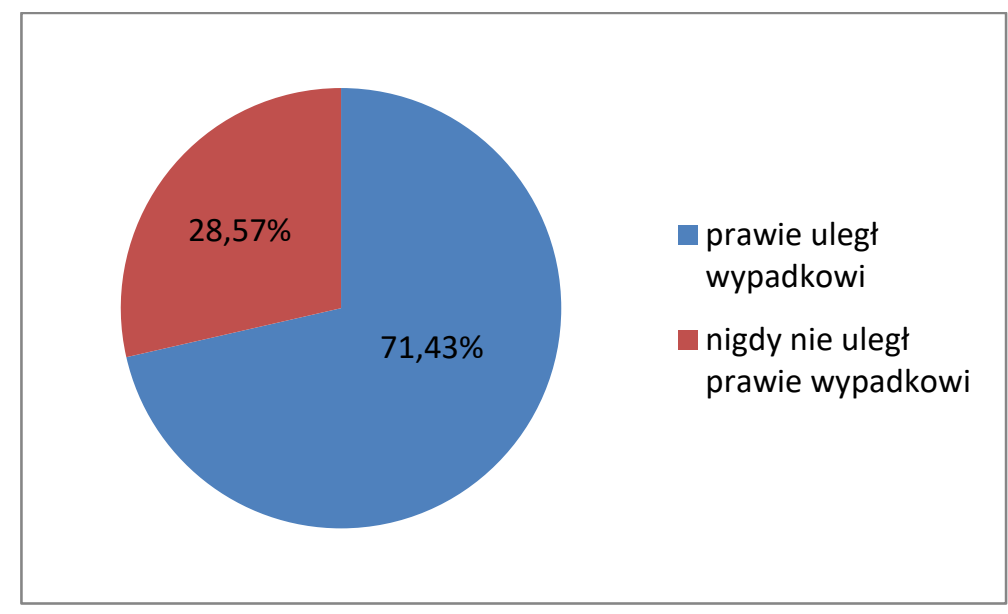

Rys. 7. Procentowy udział pracowników, którzy kiedykolwiek ulegli prawie wypadkowi przy pracy

Źródło: opracowanie własne na podstawie przeprowadzonej ankiety.

W tym przypadku $71 \%$ badanych znalazło się w sytuacji potencjalnie wypadkowej. Oznacza to, iż procent respondentów, którzy nigdy nie mieli styczności z wypadkiem przy pracy spadł z 82,14\% do 28,57\% w stosunku do poprzedniego wykresu. Wykrywanie, badanie i wyciąganie wniosków z sytuacji potencjalnie wypadkowych jest kluczowym działaniem w zmniejszaniu ryzyka zawodowego, zanim zagrożenia te nie spowodują groźniejszych skutków.

W drugiej części kwestionariusza zostały przeanalizowane kwestie związane z podejściem pracowników do pojęcia bezpieczeństwa. Rys. 8. prezentuje odpowiedzi, których udzielili badani pracownicy na 7 następujących pytań:

1) Znam definicję bezpieczeństwa i higieny pracy,

2) Znam zagrożenia występujące na moim stanowisku pracy,

3) Wiem do kogo się zwrócić w sprawach BHP,

4) Wizyta przełożonych na stanowisku pracy wywołuje niepewność i napięcie,

5) Szkolenia BHP wpływają na poprawę bezpieczeństwa pracy,

6) Wiem jak zachować się w razie wypadku,

7) U nas bezpieczeństwo i ochrona zdrowia są tak samo ważne, jak jakość i wydajność pracy.

Definicję bezpieczeństwa i higieny pracy zna 86\% badanych, a już o $18 \%$ mniej zna zagrożenia jakie występują na danym stanowisku pracy. Nieznajomość zagrożeń, które znajdują się w środowisku może skutkować sytuacjami wypadkowymi lub potencjalnie wypadkowymi. Najbardziej równomiernie rozłożone odpowiedzi respondenci udzielili przy pytaniu numer 4: "Wizyta przełożonych na stanowisku pracy wywołuje niepewność i napięcie". Przeważającą o parę jednostek odpowiedź "Tak" może być powodem stresu, który 
jest niebezpieczny dla każdego pracownika. Stres rośnie wprost proporcjonalnie do ilości zadań i ustawicznego skracania czasu na ich realizację.

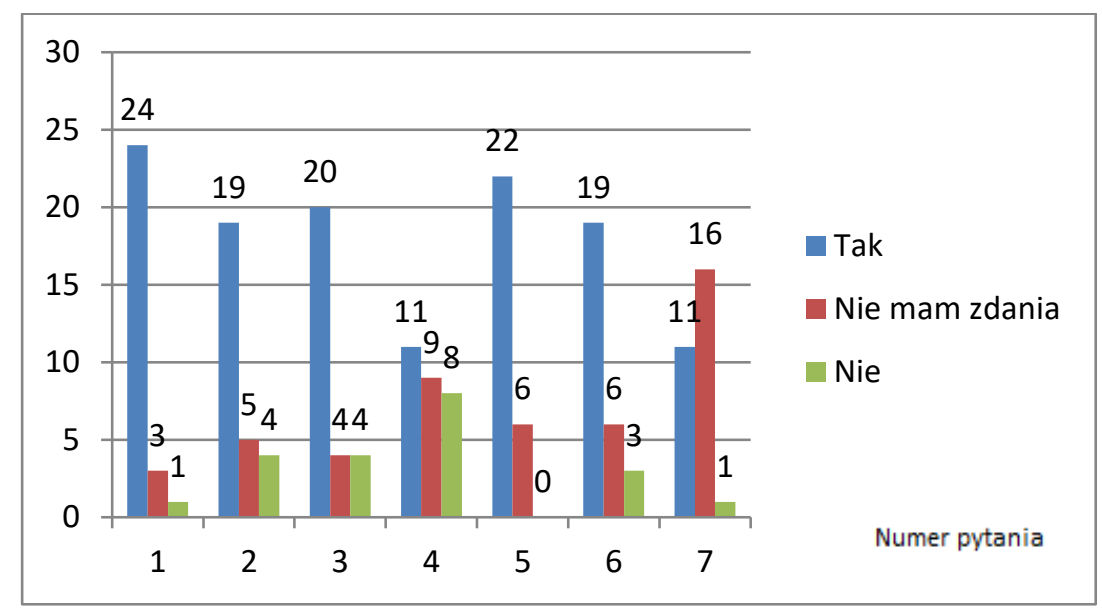

Rys. 8. Zestawienie ilości odpowiedzi na temat stosunku pracowników do bezpieczeństwa Źródło: opracowanie własne na podstawie przeprowadzonej ankiety

Im więcej i szybciej trzeba pracować, tym większe jest ryzyko stresu. Jego skutkami są: popełnianie błędów, przemęczenie, a $\mathrm{w}$ ślad za nim rozmaite dolegliwości psychosomatyczne. Zgodnie $\mathrm{z}$ hierarchią to kierownicy odpowiadają bezpośrednio przed właścicielem, a równocześnie są odpowiedzialni za swoich podległych pracowników. Tak więc kiedy oni są zestresowani często ich stres udziela się otoczeniu. Wtedy łatwiej o konflikty, kłótnie i nieporozumienia. Jak wynika również z Rys. 8. większość badanych pracowników uważa, iż szkolenia BHP wpływają na poprawę bezpieczeństwa pracy oraz wiedzą jak zachować się w trakcie wypadku. Jest to bardzo ważna deklaracja, która świadczy o przydatności szkoleń pracowników z zakresu bezpieczeństwa i higieny pracy. Ostatnim pytaniem z tej dziedziny było poznanie opinii na temat tego, czy bezpieczeństwo i ochrona zdrowia są tak samo ważne, jak jakość i wydajność pracy. W tym przypadku większość respondentów pozostawiła to pytanie z neutralną odpowiedzią "Nie mam zdania". Może być to spowodowane nieznajomością kultury bezpieczeństwa przedsiębiorstwa, w którym pracują lub chęcią złagodzenia ewentualnej odpowiedzi negatywnej. Grupa trzecia, której tytuł to "Wiedza na temat procesów magazynowania oraz transportu wewnętrznego i ich bezpieczeństwa" bezpośrednio związana jest z tematyką badań i stanowi główne źródło danych, które wykorzystano do identyfikacji obszaru problematycznego. Kolejny Rys. 9. prezentuje odpowiedzi badanych na poszczególne pytania, które na potrzebę danej pracy zostały pogrupowane, aby była widoczna zależność między procesami magazynowania oraz procesami transportu wewnętrznego. Poniżej znajduje się 10 pytań, które zostały zadane badanym pracownikom. Ułożone zostały tak, aby odzwierciedlały numerację pytań z wykresu: 
1) Znajome mi jest pojęcie procesów magazynowania,

2) Znajome mi jest pojęcie procesów transportu wewnętrznego,

3) Znam zagrożenia występujące w procesach magazynowania,

4) Znam zagrożenia występujące w procesach transportu wewnętrznego,

5) Wiem kto z współpracowników związany jest z procesem magazynowania,

6) Wiem kto z współpracowników związany jest z procesami transportu wewnętrznego,

7) Wiem do kogo się zwrócić w razie rozpoznania zagrożenia w miejscu magazynowania (np. niepoprawnie składowany towar na regale),

8) Wiem do kogo się zwrócić w razie rozpoznania zagrożenia w transporcie wewnętrznym (np. uszkodzony wózek widłowy),

9) Bywa, że wymagane zasady BHP procesów magazynowania są sprzeczne z aktualnym stanem w przedsiębiorstwie,

10) Bywa, że wymagane zasady BHP procesów transportu wewnętrznego są sprzeczne z aktualnym stanem w przedsiębiorstwie.

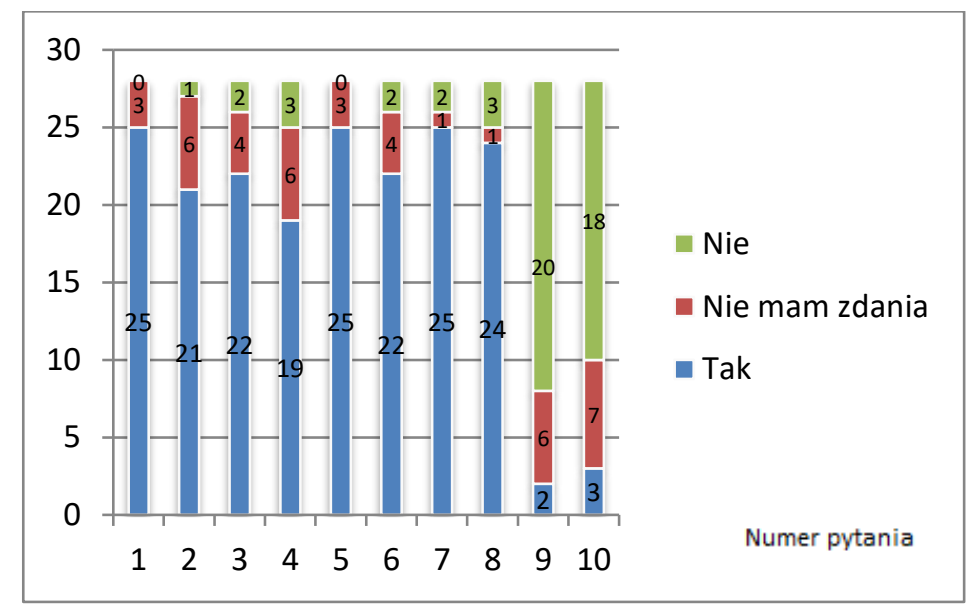

Rys. 9. Zestawienie ilości odpowiedzi na temat procesów magazynowania oraz transportu wewnętrznego i ich bezpieczeństwa

Źródło: opracowanie własne na podstawie przeprowadzonej ankiety.

Pytanie numer 1 i 2 dotyczyły znajomości pojęcia procesów magazynowania oraz znajomości procesów transportu wewnętrznego. Większość badanych odpowiedziała pozytywnie na te dwa pytania - odpowiednio $89 \%$ i 75\% zna dane procesy, jednakże między nimi jest 14\% różnicy. Oznacza to, że badani posiadają większą wiedzę na temat procesów magazynowani niżeli na temat procesów transportu wewnątrzzakładowego. Zgodnie z odpowiedziami na to pytanie, 75-78\% ankietowanych ma świadomość jakie zagrożenia mogą wystąpić w badanych procesach, jednak wciąż pozostaje kilka osób, które nie mają zdania na ten temat. Mimo, iż odpowiedzi na pytania kształtują się na podobnym poziomie świadczącym o znajomości większości respondentów zasad bezpieczeństwa i higieny pracy 
w wybranych procesach logistycznych to bardzo widoczna jest różnica między pozytywną ilością odpowiedzi na pytania związane z procesami magazynowania, a ilością odpowiedzi na temat procesów transportu wewnętrznego. Może wynikać to $\mathrm{z}$ faktu, iż $\mathrm{w}$ badanym przedsiębiorstwie produkcyjnym magazynem oraz procesami, które w nim zachodzą zajmuje się konkretna osoba - główny magazynier, a każdy z pracowników fizycznych oraz administracyjno-biurowych ma z nim kontakt na co dzień. Natomiast transportem wewnętrznym zajmują się pracownicy, którzy czynności związane z tym procesem wykonują doraźnie, wtedy kiedy zajdzie potrzeba przemieszczenia danego produktu czy wyrobu. Wciąż nie ma określonej osoby odpowiedzialnej za przemieszczanie wszystkich produktów na terenie zakładu. Ostatnia grupa pytań składała się z 5 pytań dotyczących ogólnej opinii pracowników na temat pracy. Zadane zostały następujące pytania:

1) Jestem zadowolony ze swojej pracy,

2) Praca wpływa niekorzystnie na moje zdrowie,

3) Będę w stanie zmienić pracę na inną, kiedy będę miał ponad 55 lat,

4) Jestem zadowolony ze swojego życia,

5) Z chęcią uczestniczę w przedsięwzięciach związanych z poprawą warunków pracy.

Rys. 10. przedstawia zestawienie odpowiedzi na powyższe pytania i stanowi ostatnią część ankiety.

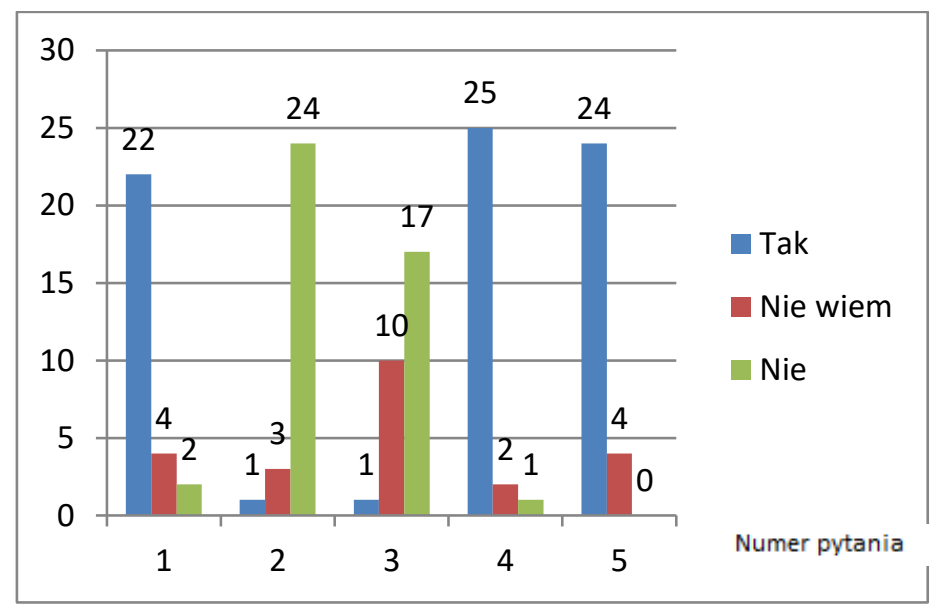

Rys.10. Zestawienie ilości odpowiedzi dotyczących opinii pracowników na temat pracy

Źródło: opracowanie własne na podstawie przeprowadzonej ankiety.

Jak wynika z wykresu tylko 7\% badanych pracowników nie jest zadowolonych ze swojej pracy co świadczy o tym, iż przedsiębiorstwo dba o swoich pracowników, by pracowało im się dobrze. W drugim pytaniu $86 \%$ ankietowanych nie uważa, aby praca wpływała niekorzystnie na ich zdrowie. Co więcej, również taki sami procent badanych z chęcią uczestniczy w przedsięwzięciach, które mają na celu poprawę jakości i bezpieczeństwa pracy. Pracownicy są otwarci na tego typu propozycje, ponieważ mają 
świadomość, że dzięki temu będą bezpieczniejsi, a praca będzie sprawiała więcej przyjemności. Większość z respondentów uważa, iż po osiągnięciu 55 lat ciężko będzie im zmienić pracę.

\subsection{Analiza wypadków, sytuacji potencjalnie wypadkowych oraz uszkodzeń mienia w latach 2010-2018}

\subsubsection{Analiza wypadków przy pracy}

Badanie i rejestrowanie wypadków przy pracy, na których składa się analiza przyczyn i okoliczności jest ważnym elementem monitorowania środowiska pracy oraz ma istotne znaczenie przy zapobieganiu kolejnych wypadków. W badanym przedsiębiorstwie produkcyjnym największa liczba wypadków związana jest z sytuacjami, które mają miejsce na hali produkcyjno-magazynowej. Nic dziwnego więc, że wypadki przy pracy najczęściej przytrafiają się pracownikom fizycznym. W przeciągu ostatnich 8 lat funkcjonowania przedsiębiorstwa, tj. od roku 2010 udokumentowane zostało 12 wypadków zakwalifikowanych jako wypadki przy pracy, w tym jednego wypadku zbiorowego, w którym uczestniczyło dwóch pracowników. Wypadek ten został zakwalifikowany jako wypadek lekki. Jedyny wypadek ciężki, który zdarzył się w zakładzie nastąpił w 2018 roku i dotyczył pracownika administracyjno-biurowego. Był on związany $\mathrm{z}$ pogorszeniem się zdrowia psychicznego pracownika spowodowanego poczuciem presji. Reszta wypadków zakwalifikowana jest jako wypadki lekkie. Na potrzeby analizy wypadków przy pracy dokonano na Rys. 11 podsumowania oraz pogrupowania rejestru wypadków, które miały miejsce w zakładzie w latach 2010-2018.

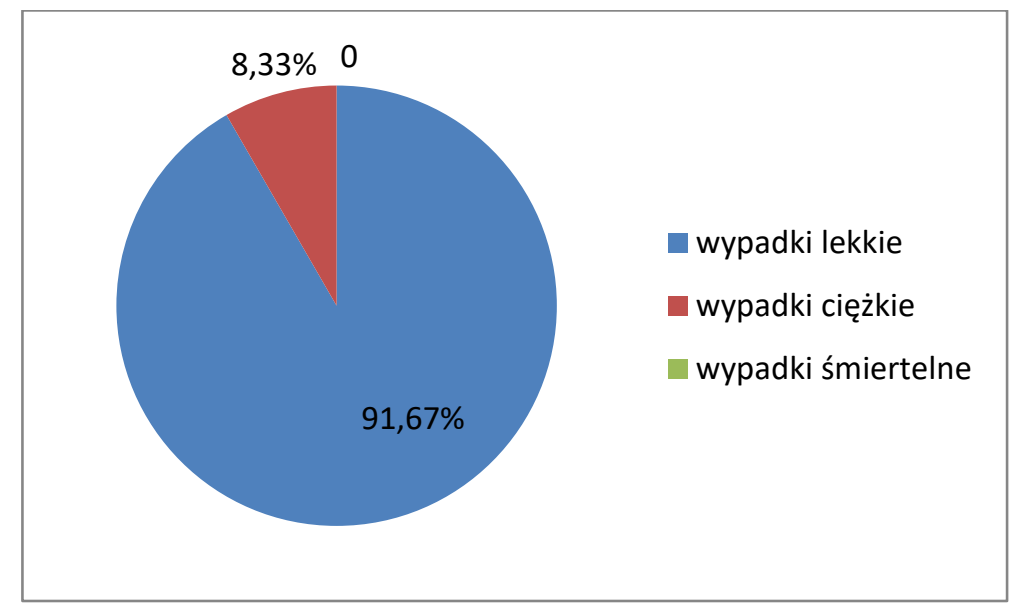

Rys. 11. Procentowy podział pracowników, którzy ulegli wypadkowi przy pracy w latach 2010-2018

Źródło: opracowanie własne na podstawie przeprowadzonej ankiety

Zgodnie z uzyskanymi na podstawie udostępnionej dokumentacji danymi na jeden rok wypada średnio 1,5 wypadku. Ze względu na ilości i kwalifikację wypadków można 
stwierdzić, iż przedsiębiorstwo produkcyjne posiada wysoki poziom bezpieczeństwa, ponieważ ponad 90\% należy do wypadków lekkich. Analiza pokazuje jednak, iż w rejestrze nie znajdują się wszystkie wypadki, które zaszły w przedsiębiorstwie. Wynika to z faktu, iż pracownicy nie zawsze mają chęć na zgłaszanie wypadku, którego doznali ze względu na wykonywanie czegoś na własną rękę, nieostrożność lub zamierzone niedbalstwo z ich strony. Może wystąpić także przypadek kiedy pracownik nie ma świadomości o możliwości zgłoszenia wypadku, który uznał za mało istotny. Zgodnie z kodami przyczyn ze statystycznej karty wypadku udokumentowane wypadki z badanego przedsiębiorstwa można podzielić na te spowodowane:

- Nieprawidłowym zachowaniem się pracownika:

- Kod 226 Zaskoczenie niespodziewanym zdarzeniem (2 wypadki),

- Kod 221 Nieznajomość zagrożenia (2 wypadki).

- Niewłaściwym samowolnym zachowaniem się pracownika:

- Kod 181 Wykonywanie pracy nie wchodzącej w zakres obowiązków pracownika (2 wypadki).

- Stanem psychofizycznym pracownika, niezapewniającym bezpiecznego wykonywania pracy:

- Kod 203 Zmęczenie (1 wypadek),

- Kod 204 Zdenerwowanie (2 wypadki).

- Brak lub niewłaściwym posługiwaniem się czynnikiem materialnym przez pracownika:

- Kod 147 Niewłaściwe uchwycenie, trzymanie czynnika materialnego (3 wypadki).

\subsubsection{Analiza sytuacji potencjalnie wypadkowych}

Na podstawie dokumentacji w postaci raportów sporządzonych przez specjalistę ds. BHP, obserwacji oraz informacji uzyskanych podczas wywiadu bezpośredniego z kierownikiem produkcji, uzyskano informacje na temat wystąpienia zdarzeń potencjalnie wypadkowych oraz tego czego najczęściej one dotyczą. Odpowiedzi pracowników fizycznych oraz pracowników administracyjno-biurowych różniły się diametralnie. Większość pracowników produkcji uważa, iż najczęstszymi sytuacjami, w których dochodzi do "prawie wypadku" są:

- potknięcie się o zostawione palety w nieprawidłowym miejscu,

- potknięcie się o liczne kable, które mimo oznakowania żółto-czarną taśmą przeszkadzają w przejściu,

- obciążenie kręgosłupa poprzez podniesienie przedmiotu/urządzenia, którego masa przekracza maksymalne dopuszczalne obciążenie pracownika, 
- obciążenie kręgosłupa oraz mięśni i rąk poprzez nieprawidłowe podnoszenie przedmiotu/urządzeń,

- kłótnie powodujące stres spowodowane niestosowaniem się do poleceń przełożonego lub ignorowanie ich.

\section{PROPOZYCJA ROZWIĄZANIA MAJĄCA NA CELU POPRAWY BADANYCH PROCESÓW W ASPEKCIE BEZPIECZEŃSTWA}

Jednym z największych wyzwań dla przedsiębiorstw w dzisiejszej rzeczywistości gospodarczej jest stworzenie, utrzymanie i rozwój procesów w nich zachodzących tak, aby były one na jak najwyższym poziomie bezpieczeństwa. Zaangażowanie pracodawcy i całej załogi w dbałość i troskę o bezpieczne warunki pracy są elementami, które determinują jej wysoki poziom (Ustawa z dnia 26 czerwca 1974 r. Kodeks Pracy). By tego dokonać warunki pracy zgodne z bhp musza być realizowane jako integralna część zarządzania całym przedsiębiorstwem. Istniejące w organizacji umocowania prawne, zarządzenia oraz procedury postępowania dotyczące bezpieczeństwa pracy tracą swą skuteczność, jeżeli nie są odpowiednio stosowane w praktyce i konsekwentnie egzekwowane. Znajomość i przestrzeganie zasad bhp w sposób niekwestionowany wpływa z kolei na zmniejszenie odsetka wypadków, absencji chorobowych oraz wyższą wydajność pracy. W przedsiębiorstwach, w których odnotowuje się wysoki poziom znajomości pojęcia i zasad bezpiecznej pracy, pracownicy czują się odpowiedzialni za siebie i współpracowników, wyrażając to w codziennej praktyce (Stankiewicz i Sznajder, 2010, s. 52). Na podstawie badań przeprowadzonych w wybranym przedsiębiorstwie można stwierdzić, że na bezpieczeństwo procesów magazynowania i transportu wewnętrznego oprócz środowiska pracy w dużym stopniu wpływają również postawy i zachowania kierownictwa i pracowników. Wyniki badań pokazują, że większość pracowników postępuje zgodnie $\mathrm{z}$ przepisami, zna zagrożenia jakie występują w środowisku pracy, jak również czuje się odpowiedzialna za bezpieczeństwo swoje i swoich współpracowników. Zauważono również, że środowisko i warunki pracy są zgodne z wymaganiami prawnymi, a wypadki zdarzają się stosunkowo rzadko. Niestety istnieją również negatywy związane z właściwą kulturą raportowania zdarzeń oraz presją wywieraną na pracownikach, co świadczy o błędach kierownictwa w zarządzaniu. Analizując osobno badane procesy łatwo było zauważyć, iż znajomość pojęcia procesu transportu wewnętrznego jak i zagrożeń w nim występujących jest mniejsza od znajomości procesu magazynowania. Przedstawia to Rys. 11 prezentujący pozytywne odpowiedzi na pytania dotyczące powyższych rozważań. 


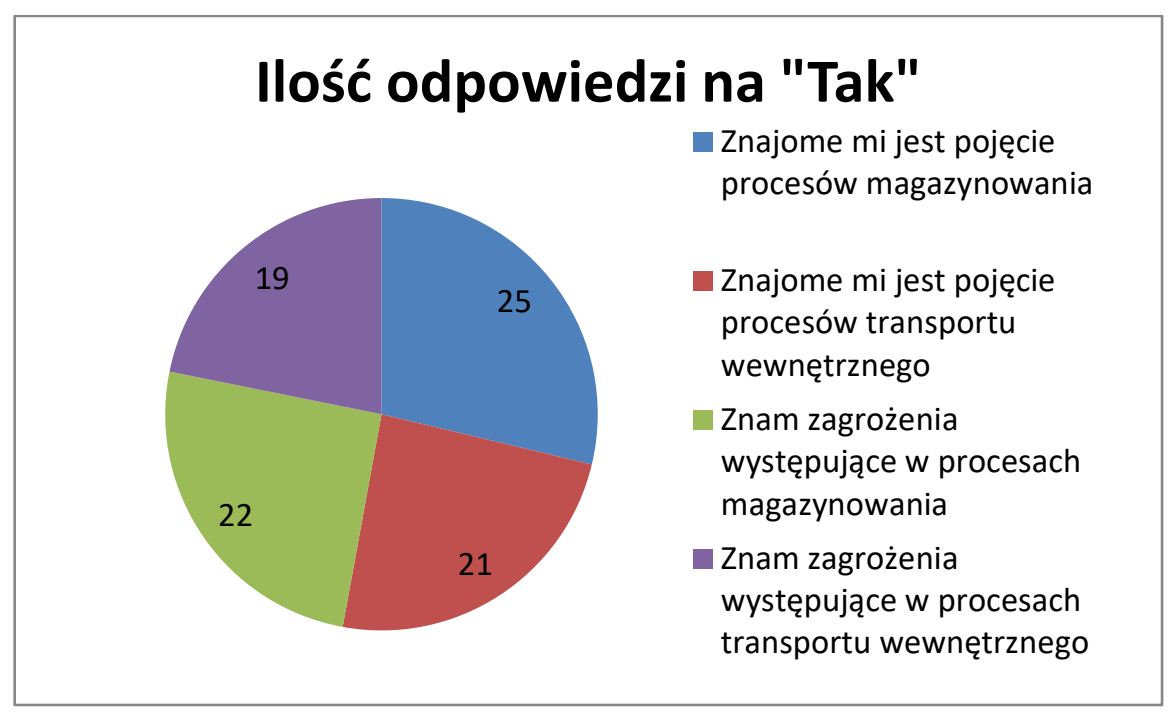

Rys. 11. Ilość odpowiedzi na "Tak" wśród badanych pracowników

Źródło: opracowanie własne na podstawie przeprowadzonej ankiety

Porównując dane odpowiedzi można zauważyć, że pojęcie procesów magazynowania jest znane dla $89 \%$ badanych, natomiast pojęcie transportu wewnętrznego dla $14 \%$ mniej. Dokładnie ta sama tendencja występuje w znajomości zagrożeń występujących w tych procesach. W związku z tym nasuwa się wniosek zwrócenia szczególnej uwagi pracowników na proces transportu wewnętrznego. Przeprowadzając szkolenia wstępne czy okresowe trzeba zaznaczać ich ważność oraz tłumaczyć najlepiej obrazując na przykładach na czym one polegają, jakie pojawiają się w nich zagrożenia oraz jaki jest ich związek z procesami magazynowania oraz pozostałymi procesami logistycznymi jakie zachodzą w zakładzie. Ocena jakości analizowanych procesów i ich bezpieczeństwa umożliwiła identyfikację i odkrycie obszarów, które wymagają poprawy i wzmocnienia. Usprawnienie ich poskutkuje optymalizacją zachodzących w zakładzie procesów logistycznych, przez co zmniejsz się czas realizacji tych procesów. Przeprowadzona analiza pozwoliła na wprowadzenie propozycji rozwiązań, które usprawnią proces magazynowania i transportu wewnętrznego oraz ich bezpieczeństwa. Zostały one przedstawione pracodawcy badanego przedsiębiorstwa. W wyniku podjętych działań do tej pory został m.in. zakupiony drugi wózek widłowy, wprowadzono tablicę zdarzeń „OMC” (o mało co), zatrudniono 2 nowych pracowników fizycznych oraz 1 pracownika umysłowego, co pozytywnie wpłynęło na bezpieczeństwo procesów.

\section{PODSUMOWANIE}

Zapewnienie bezpieczeństwa procesów logistycznych jest czynnością systemową, która wymaga podjęcia szeregu czynności (między innymi spojrzenia osobno na każdy zachodzący w niej proces), których działanie synergiczne powoduje osiągnięcie pożądanego 
poziomu bezpieczeństwa (Butlewski, Tytyk, 2011, s.128). W wyniku przeprowadzonych działań zidentyfikowano problem jakim jest stan bezpieczeństwa i jego utrzymanie na wysokim poziomie w wybranych procesach logistycznych, które zachodzą w badanym przedsiębiorstwie. Wykonano badania ankietowe wśród pracowników produkcyjnych, przeanalizowano wypadki oraz zdarzenia potencjalnie wypadkowe, które miały związek z procesem transportu wewnętrznego oraz procesem magazynowania. $\mathrm{Na}$ ich podstawie przedstawiono i dotychczas częściowo wdrożono rozwiązania, które usprawniły procesy transportu wewnętrznego i magazynowania. Każde przedsiębiorstwo produkcyjne posiada własne, specyficzne dla jego rodzaju działalności pojęcie procesów logistycznych. Na tej podstawie wprowadza się środki, które mają zapewnić bezpieczną i higieniczną pracę. Niezależnie od wielkości przedsiębiorstwa, każde zagrożenie, sytuację potencjalnie wypadkową należy brać na poważnie oraz starać się zwalczyć te zagrożenia u źródła lub ewentualnie je ograniczyć. Zgodnie z teorią W. Heinricha wypadki są często poprzedzone incydentami oraz uchybieniami/niezgodnościami wskazującymi na istnienie zagrożeń dla bezpieczeństwa (Heinrich H. W. 1959). Informacje dotyczące przyczyn tych zdarzeń są zatem ważnym źródłem wiedzy potrzebnej do wykrywania potencjalnych zagrożeń dla bezpieczeństwa. Uniknięcie najpoważniejszych wypadków (śmierć człowieka lub ciężkie kalectwo), bez względu na to czy wypadek ten zachodzi w związku $z$ procesem magazynowania, transportu wewnętrznego czy też innego procesu logistycznego, zawsze wymaga skutecznego zapobiegania, czyli działań prewencyjnych zdarzeń o niższych skutkach. Należy przy tym podkreślić znaczenie przedsięwzięć, które będą uwzględniać czynnik ludzki. Mimo, iż niektóre propozycje usprawnień zostały już wdrożone nie należy zapomnieć, iż proces utrzymania odpowiedniego poziomu stanu bezpieczeństwa jest procesem ciągłego doskonalenia, zdobywania informacji o zaistniałych zdarzeniach, wyciągania wniosków i wdrażania działań poprawiających bezpieczeństwo i redukujących ryzyka. Działania te są czynnikami determinującymi w utrzymaniu i rozwoju procesów transportu wewnętrznego i magazynowania w aspekcie ich bezpieczeństwa.

\section{LITERATURA}

1. Budzik R., Michalak J., Procesy magazynowe w przedsiębiorstwie produkcyjnym, Logistyka nr 2/2011.

2. Butlewski M., Tytyk E., Bezpieczeństwo w technice i organizacji pracy, WPP, Poznań, 2011.

3 Grzybowska K., Gospodarka zapasami i magazynem, Difin, Warszawa, 2010. 
4. Heinrich H. W.: Industrial Accidents Prevention, New York, Toronto, London, Mc Graw Hill Book Company, Inc. 1959.

5. Jarosz K., Staniszewska E., Żywiołek J., Bezpieczeństwo pracy elementem systemu zapewnienia jakości procesów magazynowych, Logistyka nr 6 (CD1), Poznań 2012.

6. Kaczmarek M., Korzeniowski A., Skowroński Z., Weselik A., Zarządzanie gospodarką magazynową, PWE, Warszawa, 1997.

7. Karczewski J.T., Karczewska K.W., Zarządzanie bezpieczeństwem pracy, Ośrodek Doradztwa i Doskonalenia Kadr, Gdańsk, 2012.

8. Krupa W.L., Zarządzanie ochroną pracy, Bezpieczeństwo i higiena pracy, Wolters Kluwer, Warszawa, 2014.

9. Niemczyk A., Zapasy i magazynowanie, Biblioteka Logistyka, 2008.

10. Rozporządzenie Ministra Pracy i Polityki Socjalnej z dnia 26 września 1997 r. w sprawie ogólnych przepisów bezpieczeństwa i higieny pracy (Dz.U. 1997 nr 129 poz. 844).

11. Skowronek Cz., Logistyka w przedsiębiorstwie, PWE, Warszawa, 2003.

12. Stankiewicz M., Sznajder M., Badanie poziomu bezpieczeństwa pracy w przedsiębiorstwie, Oficyna Wydawnicza Politechniki Białostockiej, Białystok, 2010.

13. Studenski R., Kultura bezpieczeństwa pracy w przedsiębiorstwie. Bezpieczeństwo pracy, nr $9 / 2000$.

14. Ustawa z dnia 26 czerwca 1974 r. Kodeks Pracy (Dz.U. z 2014 r., poz. 1662).

15. www.ciop.pl (24.04.2018).

16. Zbichorski Z., Organizacja transportu wewnętrznego w zakładach przemysłu maszynowego, Wema, Warszawa, 1972. 